\title{
Maximizing The Assets of a Diverse Community 1
}

Lisa A. Guion and Janet Harper Golden ${ }^{2}$

This paper is the ninth in a series of articles on planning programs to effectively outreach to diverse audiences. This series will include specialized papers on enhancing cultural competence, recruiting diverse volunteers, planning culturally appropriate marketing strategies, and other topics that are integral to the design and implementation of culturally relevant Extension education programs.

\section{Needs Verses Assets}

In every community there are needs. A need is defined as a gap or difference between a current situation and the ideal or desired situation. In Extension the needs assessment tool is used to identify what the gaps are, prioritizing those gaps and making decisions about which needs can be addressed through Extension education. Extension educators do an excellent job of developing and implementing programs to address key needs. When attempting to build programming in a diverse community, the Extension professional should also look at the assets of the community in question. Assets are defined as the strengths, skills, talents, and capabilities within a community that can be utilized to enhance that community's quality of life (Kretzmann \& McKnight, 1993).
One model that is used for community development is the asset model. The asset model recognizes that even in the most disadvantaged neighborhood there are individuals and organizations with both talents and abilities. Extension programming must identify and connect these abilities and skills. Oftentimes the assets of a community are just waiting to be tapped and maximized in an effort to make both the community and its members better off. Below are examples of the differences between needs and assets.

Needs vs. Assets.

\begin{tabular}{||l|l||}
\hline \multicolumn{1}{|c|}{ NEEDS } & \multicolumn{1}{c|}{ ASSETS } \\
\hline Focus on deficiencies & Focus on strengths \\
\hline $\begin{array}{l}\text { Result in fragmentation } \\
\text { of responses to local } \\
\text { deficiencies }\end{array}$ & $\begin{array}{l}\text { Build relationships among } \\
\text { people, groups, and } \\
\text { organizations. }\end{array}$ \\
\hline $\begin{array}{l}\text { Make people consumers } \\
\text { of services; builds } \\
\text { dependence on services }\end{array}$ & $\begin{array}{l}\text { Identify ways that people } \\
\text { can give of their talents }\end{array}$ \\
\hline $\begin{array}{l}\text { Give residents little voice } \\
\text { in deciding how to } \\
\text { address local concerns }\end{array}$ & $\begin{array}{l}\text { Empower people to be an } \\
\text { integral part of the solution } \\
\text { to community problems } \\
\text { and issues }\end{array}$ \\
\hline \hline
\end{tabular}

1. This document is FCS9225, one of a series of the Family Youth and Community Sciences Department, Florida Cooperative Extension Service, Institute of Food and Agricultural Sciences, University of Florida. Original publication date September 2005. Visit the EDIS Web Site at http://edis.ifas.ufl.edu

2. Lisa A. Guion, Ed.D., associate professor, Department of Family, Youth and Community Sciences, Florida Cooperative Extension Service, Institute of Food and Agricultural Sciences, University of Florida, Gainesville, FL 32611; Janet Harper, M.B.A., 4-H Program Leader, Pinellas County Cooperative Extension Serivce, Institute of Food and Agricultural Sciences, Largo, FL 33774.

The Institute of Food and Agricultural Sciences (IFAS) is an Equal Opportunity Institution authorized to provide research, educational information and other services only to individuals and institutions that function with non-discrimination with respect to race, creed, color, religion, age, disability, sex, sexual orientation, marital status, national origin, political opinions or affiliations. U.S. Department of Agriculture, Cooperative Extension Service, University of Florida, IFAS, Florida A. \& M. University Cooperative Extension Program, and Boards of County Commissioners Cooperating. Larry Arrington, Dean 


\section{Types of Community Assets}

Asset mapping focuses on identifying, recording, and charting the skills, talents, interests, and resources already present in a community. Asset mapping helps build on the positive resources already established in the community, and can be as simple as asking people questions verbally, or as in depth as using surveys.

We will explore three types of assets: Individual, community organizations, and formal institutions.

\section{Assessing Individual Assets}

Individual asset assessment is based on the following premises:

- Everyone has talents, skills, and gifts relevant to community activities.

- Each time a person uses his/her talents, the community is stronger and the person is more empowered.

- Strong communities value and use the skills that members possess.

- Such an approach contributes to the development of the community.

When identifying individual assets, you should explore several areas.

First, ask people for a list of their knowledge and abilities. Have the individual list skills learned at home and in the community. Then work with the individual to identify which of those skills are the most valuable or needed in the community. Embrace these skills as the very foundation of community building. Second, look at community skills. You need to identify types of community activities that an individual has participated in, and then you need to find out what kind of community work the individual would be willing to do in the future. Third is the area of enterprising interests and experiences. Individuals are allowed to identify skills that could be used to launch small businesses and skills that may be used in a trade or vocation.
In assessing individual assets, the Extension professional will reap benefits for developing programs that target audiences will enjoy and find valuable. The individual community members will benefit because they are able to see the assets that they possess (as well as how to use them), and the community will benefit because these assets could be utilized to further the community from within.

\section{Assessing Community Organization Assets}

When used with community associations, groups, and organizations, the asset assessment is based on the idea that every community has people who work together to pursue common goals. These groups may be formal or informal, and usually function by carrying out three key roles:

- deciding to address an issue/problem of common interest;

- developing a plan (formal or informal) to address the issue; and,

- carrying out the plan to resolve the problem.

Community organizations are critical to the success of extension programming because they involve, empower, and affect local citizens.

\section{Assessing Formal Institution Assets}

As we look at formal institutions, the assets assessment process promotes the basic premise that every community has a variety of public, private, and not-for-profit formal institutions that carry out ongoing community functions so that the social needs of a community are met. There are five steps involved in assessing the assets of formal institutions:

1. Recognize that the local institutions represent important assets to the community.

2. Do an inventory of the institutions existing in the community.

3. Identify the type of activities in which these institutions are involved. 
4. Explore the type of links that can be built between these institutions, as well as between the institutions, local individuals, and informal organizations.

5. Seek the assistance of local institutions as conduits to resources outside the target community.

Some ways that formal institutions can help the community include purchasing locally, hiring locally, training local residents, developing human resources, sharing meeting space, initiating local investment strategies, mobilizing external resources and sharing other resources. By understanding the assets of formal institutions we can better understand how they, communities, and individuals can come together to achieve a desired outcome.

\section{Conclusion}

The Extension professional must develop programs that will build on the assets of a diverse community. Once you have identified the assets of the community, you must take another look at how these assets can work together. If we review assets, we may see new ways for people and groups to work together. On the other hand, we may learn why groups have not been able to work together in the past.

While it is certainly important to assess the needs of a community, it is equally if not more important to tap into the assets of that community. By utilizing the identified assets of the community itself, as well as the individuals of that community and the community organizations, you will get the residents involved in building their community into a more cohesive group. The residents will feel that they have a stake in what is taking place. In other words, if you involve the community in programming, you empower the members by making them part of the solution. (For more information on asset mapping, please read Unit 4 of the Strengthening Programs To Reach Diverse Audiences curriculum, http://fycs-diversity.ifas.ufl.edu/)

\section{References}

Beaulieu, B. (2002). Mapping the assets of your community: A key component for building local capacity. Mississippi State, MS: Southern Rural Development Center.

Guion, L. A., Goddard, H. W., Broadwater, G., Chattaraj, S., \& Sullivan-Lytle, S. (2003).

Strengthening programs to reach diverse audiences. Gainesville, FL: Florida Cooperative Extension, University of Florida.

Kretzmann, J. P., McKnight, J. L., and Puntenney, D. (1998). A guide to creating a neighborhood information exchange: Building communities by connecting local skills and knowledge. Chicago, IL: ACTA Publications.

Kretzmann, J. P., \& McKnight, J. L. (1993). Building communities from the inside out: A path toward finding and mobilizing a communitys assets. Chicago, IL: Northwestern University for Urban Affairs and Policy Research

\section{EDIS Fact Sheets in the Planning Culturally Relevant Programs Series}

1. Guion, L.A. (2005). An Overview of Diversity [Online]. EDIS. Florida Cooperative Extension Service, University of Florida. http://edis.ifas.ufl.edu/FY752

2. Guion, L.A. (2005). Reaching Diverse Audiences [Online]. EDIS. Florida Cooperative Extension Service, University of Florida. http://edis.ifas.ufl.edu/FY753

3. Guion, L.A., \& Brown, K. (2005). Culturally Competent Extension Educators [Online]. EDIS. Florida Cooperative Extension Service, University of Florida. http://edis.ifas.ufl.edu/FY754

4. Guion, L.A., \& Harper Golden, J. (2005). Culturally Diverse Advisory Boards and Volunteers [Online]. EDIS.Florida Cooperative Extension Service, University of Florida. http://edis.ifas.ufl.edu/FY755 
5. Guion, L. A., \& Walker, N. (2005). Planning Programs to Break Down Cultural Barriers [Online]. EDIS. Florida Cooperative Extension Service, University of Florida. http://edis.ifas.ufl.edu/FY756

6. Guion, L. A. (2005). Personal Marketing: A Strategy for Marketing Programs to Diverse Audiences [Online]. EDIS. Florida Cooperative Extension Service, University of Florida. http://edis.ifas.ufl.edu/FY757

7. Guion, L. A.,\& Kent, H. (2005). Ethnic Marketing: A Strategy for Marketing Programs to Diverse Audiences [Online]. EDIS. Florida Cooperative Extension Service, University of Florida. http://edis.ifas.ufl.edu/FY758

8. Guion, L. A., \& Kent, H. (2005). Relationship Marketing: A Strategy for Marketing Programs to Diverse Audiences [Online]. EDIS. Florida Cooperative Extension Service, University of Florida. http://edis.ifas.ufl.edu/FY759

9. Guion, L.A., \& Harper Golden, J. (2005). Maximizing The Assets Of A Diverse Community [Online]. EDIS. Florida Cooperative Extension Service, University of Florida. http://edis.ifas.ufl.edu/FY760

10. Guion, L. A. (2005). Enhancing Instruction To Connect With Diverse Audiences [Online]. EDIS. Florida Cooperative Extension Service, University of Florida. http://edis.ifas.ufl.edu/FY761 